\title{
HEALTH AND HOUSING IN VICTORIAN LONDON
}

\author{
M. J. Daunton
}

\section{I}

In January 1908, the council of the London borough of Islington met to consider a report from the Medical Officer of Health which indicated that the level of infant mortality was the same as in the $1840 \mathrm{~s}, 146$ per 1,000 . A resolution was moved that three paid health visitors should be appointed as part of a campaign to reduce this heavy toll; also before the council was a protest from the Holloway and District Ratepayers Association against such a scheme. The motion was lost by 36 votes to 17 . "The spectacle before them", remarked Alderman Mills, "was that of a Council haggling with a grizzly skeleton while they clutched at the money bags to see if they could save a sovereign". 1

This minor incident in the council chamber of one North London borough raises a major issue concerning the relationship between health and housing, for housing had two identities which could come into conflict in their impact upon urban health. A house was not only a place of residence that might be more or less salubrious, it also provided the basis of the system of local-government finance and hence a large part of the income for improvements in the urban environment which were designed to make London more healthy. Rates fell particularly heavily on the owners of house property. A merchant or a solicitor or shopkeeper paid rates on the office or store from which he ran his business, but this sum was not directly related to income or turnover, and might form a small proportion of his total costs. It was different for a landlord who was paying a tax directly related to his income. ${ }^{2}$ There might therefore be a tension between increasing rates to finance better sanitation, and a mounting fiscal burden on rented houses. The incidence of the rates might fall upon the owners, so squeezing their profit margins and making them disinclined to keep property repaired or to provide additional accommodation; or the incidence might fall upon the tenants, in which case

Professor M. J. Daunton, Department of History, University College London, Gower Street, London WC1E 6BT

This paper was delivered as a lecture at the Wellcome Institute for the History of Medicine in May 1985. It drew upon my recent book House and home in the Victorian city: working-class housing 1850-1914, and a chapter for the Cambridge social history of Britain. It is therefore a synthesis and summary rather than a piece of original research.

\footnotetext{
${ }^{1}$ A. Offer, Property and politics, 1870-1914: landownership, law, ideology and urban development in England, Cambridge University Press, 1981, 296-7.

2 E. P. Hennock, 'Finance and politics in urban local government in England, 1835-1900,' Hist J., 1963, 6: $212-25$.
} 
pressure was placed on working-class incomes. This tension between the two facets of housing in relation to health-as a place of residence and the basis of local finance-had become very clear by the late-Victorian period, and culminated in an Edwardian crisis in the London property market.

The debate on The bitter cry of outcast London in the early 1880s, which produced the Royal Commission on the Housing of the Working Classes, led many to accept that in order to maintain the health of the majority of the population, it might be necessary to set aside the property rights of the few who provided rented accommodation to the working class. The Marquis of Salisbury, the leading advocate of the appointment of a Royal Commission and subsequently Conservative Prime Minister, caused alarm in some quarters in 1883 when he advocated cheap state loans to encourage the work of the philanthropic housing trusts, and stricter sanitary regulation of suburban development. Parliament, he pointed out, allowed the provision of new streets, railways, and public buildings in London which swept away the homes of the poor; in this case it was quite right for Parliament to intervene to increase the supply of accommodation. "Laissez faire is an admirable doctrine; but it must be applied on both sides." 3 This appeared to some to be insidious socialism: the Liberty and Property Defence League, which was formed in 1882, preferred to argue that problems were created by government over-regulation, and expressed alarm at the possible extension of state control into wider aspects of working-class life. The League, associated with the opposition to "medical despotism" in mid-Victorian Britain, drew upon the supporters of the Personal Rights Association, which had in turn emerged from the campaign against the Contagious Diseases Acts, and which also opposed the compulsory vaccination laws of 1853 and after. The League supported "free labour" against trade unions, and opposed the extension of municipal trading through municipal ownership of public utilities. ${ }^{4}$ The League did not achieve much support, a fact which had alarming prospects for the house-owners, for whom housing was more than an aspect of the sanitary problem; houses were to them an economic activity in their own right, and one of great significance.

The word "landlord" usually summons up the vision of such rapacious villains as Sartorius in Shaw's Widower's Houses, who, living in the comfort of Surbiton with its gravel soils and low death rate, sent rent collectors like the despised Lickcheese to the East End to extort money from the poor. "Look at that bag of money on the table", Lickcheese demands of Sartorius in the scene at the heart of the play, "Hardly a penny of that but there was a hungry child crying for the bread it would have bought". 5 The same vision appeared in a Punch cartoon of 1883, at the height of the concern about "outcast London": a bloated and over-fed rent collector bearing a bag labelled ' 50 per

\footnotetext{
${ }^{3}$ For the debate on The bitter cry and the Royal Commission on the Housing of the Working Classes, see the divergent views of G. Stedman Jones, Outcast London: a study in the relationship between classes in Victorian society, Oxford University Press, 1971, ch. 11; and A. S. Wohl. The eternal slum: housing and social policy in Victorian London, London, Edward Arnold, 1977, chs 8 and 9. Salisbury's intervention in the debate is reprinted in A. S. Wohl (ed.), Andrew Mearns, The bitter cry of outcast London, with leading articles from the Pall Mall Gazette of October 1883 and articles by Lord Salibury, Joseph Chamberlain and Forster Crozier, Leicester University Press, 1970.

${ }^{4}$ Wohl, Eternal slum, 231 - 4; E. J. Bristow, 'The Liberty and Property Defence League and individualism', Hist. J., 1975, 18: 761-89.

${ }^{5}$ G. Bernard Shaw, The complete play's of George Bernard Shaw, London, Odhams, 1934, 1-28.
} 
cent' faces a working man, his bedraggled wife and children in a room whose only decoration is a price list for the manufacture of match-boxes at $2 \frac{1}{4} d$. a gross. "Now, then, my man; week's hup! Can't 'ave a 'ome without paying for it, yer know!"6 This view of "Mammon's rents" was no doubt part of the truth, but it must always be remembered that it was only part.

Although there were some large-scale owners like Sartorius, much more typical of the owners of small house property in Victorian London were members of the petty bourgeoisie or even the more prosperous artisans, who bought a few houses to provide an income and security for themselves in old age and for their dependents after their death. They were attracted by local investments, which were concrete and visible, and appeared to offer greater security than the bonds and stocks preferred by wealthier members of society. The few houses owned by these people were of great importance in the life-cycles of their families; the best analogy would be a pension fund. ${ }^{7}$ The problem, however, was that housing was not only in its own right an economic asset that was expected to provide an income to its owner: it was also a precondition for other economic activities. Poor housing conditions could mean an inefficient and unproductive work-force, with a high incidence of disease and death. This had become obvious from the 1840s, when the first controls on housing standards were imposed in such provincial towns as Liverpool, and which were extended and codified in the Public Health Acts, most obviously that of $1875 .^{8}$ The legislation in London was different from the provinces, for the metropolis had Building Acts dating back to the seventeenth century following the Great Fire, which had been consolidated in the London Building Act of $\mathbf{1 7 7 4}$. This Act was essentially concerned with limiting the spread of fire, preventing encroachments into the streets, and controlling dangerous structures; it was not concerned with matters of health. Nevertheless, it was an important precedent for public control over building in towns, and formed the basis of the first, albeit unsuccessful, attempts to create a national building code in 1841 . Although the national legislation did not pass, the Metropolitan Building Act of 1844 did incorporate into London legislation some of the proposals which had emerged in the debate, such as controls over street widths, obnoxious trades, and habitable cellars. Drainage and sanitation were still excluded, and it was in 1855 that this shortcoming was rectified, with the Metropolis Local Management Act. The Metropolitan Building Act had consolidated and modified the technical building regulations, and the new Act

\footnotetext{
${ }^{6}$ Punch, 10 November 1883, reproduced in H. J. Dyos, 'The slums of Victorian London', Victorian Studies, 1967, 11: 21 .

${ }^{7}$ See R. J. Morris, 'The middle class and the property cycle during the industrial revolution', in T. C. Smout (ed.), The search for wealth and stability, London, Macmillan, 1979, 91-3; and idem, 'The middle class and British towns and cities of the industrial revolution, 1780-1870', in D. Fraser and A. Sutcliffe (eds), The pursuit of urban history, London, Edward Arnold, 1983, 295.

${ }^{8}$ On the introduction of controls in Liverpool, see A. Errazurez, 'Some types of housing in Liverpool, 1785-1890', Town Planning Review, 1943-7, 19: 59-68; and I. C. Taylor, 'The insanitary housing question and tenement dwellings in nineteenth-century Liverpool', in A. Sutcliffe (ed.), Multi-storey living: the British working-class experience, London, Croom Helm, 1974. The national development is described in R. Harper, Victorian building regulations: summary tables of the principal English building acts and model bye-laws, 1840-1914, London, Mansell, 1985; and S. M. Gaskell, Building control: national legislation and the introduction of local bye-laws in Victorian England, London, British Association for Local History, 1983.
} 


\section{Health and housing in Victorian London}

controlled cellars, streets, and drainage. Where London lagged behind the provinces was in control over such matters as damp-proof courses, underfloor ventilation, and composition of mortar; the legislation remained somewhat inflexible in the face of change, and was much less responsive than the building by-laws which were being introduced in provincial towns. London was excluded from the operation of the Public Health Act of 1875, which codified powers relating to these by-laws, and was not covered by these model by-laws of 1877 issued by the Local Government Board. Although the London Acts were amended on a number of occasions, it was not until 1894 that a comprehensive London Building Act regulated the metropolis to the same standard as other English towns. ${ }^{9}$ Of course, much of the new housing was constructed in areas like West Ham, which fell outside the area of the London Building Acts and came within the scope of the Public Health Act. There was a problem with these regulations, that by improving housing standards, rent levels might be pushed above working-class incomes, and produce sub-letting for which self-contained single-family houses were not designed. At the same time as standards were pushed up, housing had to bear the burden of the rates, which paid for such major improvements in the public health of London as the new main drainage system designed by Joseph Bazalgette for the Metropolitan Board of Works. ${ }^{10}$ In this lay the potential for conflict between housing as an investment earning a reasonable return, and as a precondition for other economic activities requiring a healthy work-force.

This conflict was to remain potential, rather than actual during much of the Victorian period, when it was possible for housing standards to improve and for the level of expenditure on local government to rise without an insuperable threat to the owners of small house property. This was for two main reasons, namely the buoyancy in both the rate base and in working-class incomes. During a period of rapid urban growth such as the mid-nineteenth century, it was possible for the expansion of the rateable value of towns to keep pace, or at least to catch up with, the need for costly interventions in the urban environment. London did, it is true, have a particular problem because of the variation between prosperous areas with high rateable value and low outgoings, and poor areas with low rateable value and high outgoings, which led to schemes to "equalize" the rates of various parts of the metropolis which started in $1867 .{ }^{11}$ This was essentially a matter for administrative reform, but by the end of the nineteenth century something more than an equalization of rates between areas was required; what was needed was a change in the basis of local government finance away from small house property to other sources of income, which was a much more difficult issue. The problem had arisen because of a lower rate of growth of rateable value, which accompanied the end of rapid urbanization and the displacement of population to areas outside the limits of the London County Council where it could not contribute to the costs of London government. Between 1871 and 1881 , the rateable value of

\footnotetext{
${ }^{9}$ Harper, op. cit., note 8 above; and C. C. Knowles and P. H. Pitt, The history of building regulation in London, 1189-1972, London, Architectural Press, 1972.

${ }^{10}$ See D. Owen, The government of Victorian London, 1855 89, Cambridge, Mass., and London, Belknap Press of Harvard University Press, 1982, ch. 3; and F. Sheppard, London, 1808-70: the infernal wen. London, Secker \& Warburg, 1971, ch. 7.

${ }^{11}$ Owen, op. cit., note 10 above, 314.
} 


\section{J. Daunton}

London rose by 38.4 per cent, but between 1891 and 1901 by only $20 \cdot 1$ per cent. ${ }^{12}$ The costs of urban government had at the same time risen and the boroughs became much more insensitive to pressure from groups of ratepayers, despite the success of the Holloway and District Ratepayers Association in 1908. The influence of such bodies was usually curtailed by the rise of other pressure groups such as Trades Councils; by the creation of a professional executive of engineers, town clerks, and medical officers, which eroded the independence of the councillors; and by the imposition of central government controls. A ratepayers' backlash against higher rates had become less likely, as had the possibility that the growth in rateable value would catch up with expenditure. ${ }^{13}$ This would not necessarily have mattered to the owners of small house property if the costs of increased standards of construction and the higher burden of rates could have been passed to the tenants in the form of higher rent, but this was also ceasing to be possible in the late nineteenth and early twentieth centuries, as the earlier buoyancy in working-class incomes turned to stagnation.

In the last quarter of the nineteenth century, there had been a massive reduction in the price of food and manufactured goods, without a corresponding reduction in wages. The result was a marked improvement in real wages for the majority of the urban working class, whatever exceptions there were in particular occupations. ${ }^{14}$ The higher real income could be spent in a number of ways: on the purchase of a wider range of foodstuffs with a higher consumption of meat; on new consumer goods such as bicycles or linoleum; or on the developing commercial leisure of music halls and sport. It could, however, also be spent on housing, for rents formed the major exception to the fall in prices in the later nineteenth century (table 1).

TABLE 1. RENTS, PRICES AND REAL WAGES, 1870-1910

\begin{tabular}{cccc}
\hline & House rents & Price index & Real wage index \\
\hline 1870 & 100 & 100 & 100 \\
1888 & 116 & 76 & 143 \\
1898 & 123 & 71 & 165 \\
1910 & 130 & 88 & 163
\end{tabular}

Sources: H. W. Singer, 'An index of urban land rents and house rents in England and Wales, 1845-1913', Econometrica, 1941, 9: 230; B. R. Mitchell and P. Deane, Abstract of British historical statistics, Cambridge University Press, 1962, 344-5, 472-3.

This was not the result of an increase in the profit margin of the owners; rather, it reflected the increased standard of accommodation, and the ability to pass the costs both of higher standards of construction and rates on to the tenant. In theory, it is true, the occupier and not the owner of a small house was liable for payment of the rates, but in many cases the landlord agreed to "compound" or to collect the rates on behalf of the local authority as part of the weekly rent, in return for an allowance. In practice, it

\footnotetext{
12 London County Council (LCC), London statistics, vol. 16 (1905-6), 478.

${ }^{13}$ For an account of the operation of this backlash and its subsequent curtailment, see E. P. Hennock, Fit and proper persons: idea and reality in nineteenth-century urban government, London, Edward Arnold, 1973; and Offer, op. cit., note 1 above, 221-7.

${ }^{14}$ See E. P. Phelps Brown with M. Browne, A century of pay: the course of pay and production in France, Germany, Sweden, the United Kingdom and the United States of America, 1860-1960, London, Macmillan, 1968.
} 


\section{Health and housing in Victorian London}

was not always possible for the owner to pass an increase in the rates on to the tenant, with the result that the portion of the tenant's weekly payment that went to the landlord was reduced. There were fluctuations in the incidence of the increased costs, depending upon the state of the housing market. At a time of overbuilding and a consequent high level of vacancies, the landlord was likely to bear the costs; when there was a tight housing market, as in the early 1890 s, the tenant would be forced to do so. In a period of rising working-class real incomes, it was possible for tenants to bear part of the cost and to preserve the landlords' profit margins. From the late 1890s this changed, and there was consequently a serious decline in the profit margin of the landlords. After 1896, prices in general started to rise and wages did not keep pace, so that working-class real incomes stagnated until the First World War. The level of effective demand for housing was therefore low, and this coincided with a glut in the housing market after the building boom at the turn of the century. The outcome was that the burden of rising costs - whether construction, interest, or local taxation-fell upon the owners. ${ }^{15}$

The opposition of the Holloway and District Ratepayers Association in 1908 to the employment of health visitors is therefore not surprising. The increase in the rates to improve the health of the urban environment was in fact a capital levy upon house owners, threatening the security they had planned when investing in this property. In 1880 , rates were 16.4 per cent of the total of rent and rates for working-class houses in London; in 1900, the figure was 20.3 per cent. ${ }^{16}$ In Islington, the rate in the pound had increased from around $4 s$. in the $1870 \mathrm{~s}$ to $5 s$. in $1891,7 s$. in 1901, and $8 s$. in 1911. The price of housing may be expressed as "years' purchase" or multiples of the annual rent: in Islington, the price of houses had fallen from 9.4 years' purchase in 1892 , to 7.6 in 1902, and 4.0 in 1912. ${ }^{17}$ The cost of the improvement of the physical and social infrastructure of Victorian and Edwardian London, which contributed to the falling mortality of the capital, was met from a tax on house rents, which produced a crisis in the housing market. The attempt to create healthy housing of a good standard of construction connected to a piped water supply and mains drains had, because of the shortcomings of the system of local taxation, produced a check to the provision of additional accommodation, which threatened a deterioration in housing standards.

How this Edwardian crisis would have been resolved can only be a matter of speculation, for it was overtaken by a much graver crisis during the First World War. By 1914, the vacancies created by the building boom around 1900 had largely been taken up, and this produced the precondition for a rise in rents and a possible recovery in profit margins, even if at the risk of imposing serious strain on tenants faced by stagnating real wages. As it was, this free-market mechanism of recovery from a cyclical downturn was aborted by the rent controls introduced by the government in 1915; even if the Edwardian crisis were merely cyclical rather than a permanent

\footnotetext{
${ }^{15}$ M. J. Daunton, House and home in the Victorian city: working-class housing, 1850-1914, London, Edward Arnold, 1983, 215.

16 Offer, op. cit., note 1 above, 290-2, 311; PP, 1905, LXXXIV, Second series of memoranda, statistical tables and charts prepared in the Board of Trade with reference to various matters bearing on British and foreign trade and industrial conditions.

${ }^{17}$ Offer, op. cit., note 1 above, 270.
} 


\section{J. Daunton}

structural change in the housing market, it soon changed its character. Whether a free market solution would have been possible can, however, only be a matter of mere speculation: the deterioration in profit margins might have gone too far; and the fiscal problem might not have been solved. ${ }^{18}$ What is undoubtedly true is that, before 1914 , the interests of small property owners had been neglected and they were forced to bear the burden of the improvements in the public health of London. It is worth asking why this should have been the case.

House owners were, of course, aware of their plight, and were conscious that purely local victories such as that at Islington in 1908 were not enough: what was needed was a change in taxation policy at Westminster rather than the frustration of the Medical Officer of Health in Islington. There were, however, difficulties in the way of a widening of the political stage, arising both from the characteristics of the property owners themselves and from the terms of the political debate in which they were obliged to participate. The nature of the investment as local, concrete, and secure indicated a limitation of horizon which was political as well as economic; it was an expression of a dominant localism that could not adjust to the need for a movement away from the older strategy of ratepayers' backlash on the local council and towards mobilization at Westminster. In any case, the petty bourgeoisie of England had supported a laissez faire ideology in the early nineteenth century as part of an attack upon the privileges and limitations that seemed to deny them political and economic rights. This was a view of the state as biased and parasitical, and generally it continued to be held by organized property owners throughout the nineteenth century. They were accordingly opposed to state intervention and municipal socialism, although it could be argued that intervention on their behalf was precisely what they needed. The state was viewed as a hostile agency and not as something that could be used for their own ends. This forms a contrast with Germany, where later industrialization allowed the longer survival of pre-industrial corporate bodies of small traders, while the earlier rise of large-scale concerns created an opponent to be fought by appeals to the state. ${ }^{19}$

This weakness of the position of British owners of house property was intensified by the problems that arose from the terms set by the political debate which developed from the $1880 \mathrm{~s}^{20}$ The Liberals came to see the solution to the fiscal problem as a tax on land. The builders and owners of the houses were considered to be productive and enterprising, whereas the owners of land were felt to be parasitical, imposing a burden on others in the form of high land prices created not by their own efforts, but by the general expansion of the economy. This was an "unearned increment" which should be taxed out of existence, providing an alternative source of income for urban government that would relieve house property of its burden. This was to prove to be impractical, for the share of the national income accruing to land was not large enough

\footnotetext{
${ }^{18}$ Daunton, op. cit., note 15 above, ch. 12; Offer, op. cit., note 1 above, argues for a permanent structural change.

${ }^{19}$ G. J. Crossick, 'Urban society and the petty bourgeoisie in nineteenth-century Britain', in Fraser and Sutcliffe (eds), op. cit., note 7 above, 307-26; and idem, 'The emergence of the lower middle class in Britain: a discussion', in G. J. Crossick (ed.), The lower middle class in Britain, 1870-1914, London, Croom Helm, $1977,39-48$.

20 These comments are based on Offer, op. cit., note 1 above.
} 


\section{Health and housing in Victorian London}

to bear the burden proposed by the Liberals, and it was difficult to value land separately from the buildings erected on it. The policy certainly had a limited appeal to most house owners, who in many cases were themselves the owners of the plots upon which the houses were erected. Even in London, where the leasehold system was preponderant and the owners of land and building were usually different, there was more co-operation than conflict. The organized property owners were more inclined to side with the landowners than against them as the Liberals had assumed they would. The main importance of the Liberal campaign against landowners was that it diverted attention from the solutions that the house owners would have preferred, such as a local income tax or a greater reliance upon central government for funds, both of which would have broadened the tax base. Nor did the Conservatives come to the protection of the house owners. Salisbury's government neglected urban interests in its reforms of the taxation system, providing instead relief for the Church and agriculture; there was a disinclination to protect an unpopular element of property. Rather than come to the aid of the small property owners in Edwardian Britain, some Conservative opponents of the Liberal land campaign were advocating council housing: the solution to the discrepancy between healthy housing and profit, between housing as a residence and a source of taxation, seemed to be to remove it from the private sector.

Public health reform and pressure for improved housing must therefore be seen against this background of an unresolved dilemma of local taxation which created the spectacle described by Alderman Mills. The problem was, as Dr Offer has said,

If the production of goods and the maintenance of labour were to be kept at a level of competitive efficiency, urban conditions had to be ameliorated and improved. Revenue for local rates fell short of satisfying these pressing requirements but taxation of houses was already high enough to choke off the market supply of new housing and cause existing accommodation to be run down. ${ }^{21}$

\section{II}

The concern for the housing of London, which had surfaced in Andrew Mearns's The bitter cry of outcast London, arose from specific problems in one part of the London housing market, in what would now be called the inner city, the band between the expanding business district and the new suburbs. It was a world, as described by Mearns, of "pestilential human rookeries", in which dilapidated houses were subdivided so that "every room in these rotten and reeking tenements houses a family, often two", resulting in overcrowding and all kinds of sexual immorality and vice. His starting-point was the impossibility of evangelizing the poor who lived in such conditions: his concern was primarily with moral health rather than physical health. ${ }^{22}$ The pamphlet marked the start of a major debate in the 1880 s about the housing of London's poor, and it might be wondered why this was the case. Bad housing conditions were, after all, not a novel feature of the metropolis, and concern had often been expressed during the previous half-century.

${ }^{21}$ Ibid., 310.

22 Wohl (ed.), Andrew Mearns, op. cit., note 3 above. 


\section{J. Daunton}

What was at stake was in part a relative deterioration of inner London, a failure to share in the general improvement in housing conditions experienced in most large towns since the 1860 s. Indeed, certain parts of inner London seem to have experienced an absolute decline in standards, measured in terms of persons per house (table 2).

TABLE 2. PERSONS PER HOUSE IN SELECTED AREAS OF LONDON, 1841-81

\begin{tabular}{lcrc}
\hline & 1841 & 1861 & 1881 \\
\hline Holborn: St George's & 8.6 & 10.4 & 11.4 \\
Bethnal Green: Green & 6.0 & $7 \cdot 1$ & 7.9 \\
St George in the East: St John's & 6.2 & 9.8 & $10 \cdot 3$ \\
\hline Source: Stedman Jones, Outcast London, op. cit. & note 3 above 176
\end{tabular}

This might be compared with an area such as Tyneside, whose housing conditions were as bad as London's but where there was some optimism about the situation: in 1854, 65.3 per cent of families in Newcastle lived in subdivided tenements and 34.7 per cent in self-contained houses and flats; by 1883-5, the figures were reversed at 35.7 and 64.3 per cent respectively. ${ }^{23}$ Inner London stood out from the national trend away from the subdivision of existing housing (which had marked urbanization in the early nineteenth century) and towards self-contained property. In some ways, the problem seemed to be intensified in the $1880 \mathrm{~s}$, and its scale meant that it could not, as in provincial towns, be treated as a regrettable but isolated incident in the general improvement of housing conditions. How is this situation to be explained?

It was the product of a number of factors in both the housing and labour markets that were either peculiar to London or particularly intense, which came together in an unprecedented way in the 1880 s to create a crisis for the casual poor. Employment in London had a number of peculiarities which must be remembered in any analysis of the housing market. ${ }^{24}$ There were, of course, many men with regular employment and high wages: civil servants, clerks in the various financial and commercial firms of the City, workers for the railway companies, skilled craftsmen of various sorts. There was also a unique mixture of functions which created a large casual labour market that trapped the population of the inner city in a limited and shrinking stock of expensive and poor-quality housing. London was the major port in the country; it was the centre for conspicuous consumption by the court, the aristocracy, rentiers, and all those attracted to the capital for business and pleasure; and it remained a major industrial centre. The trade which passed through the port was seasonal, depending upon the harvest for various crops such as wheat or the opening of the Baltic for timber. There were also shorter-term irregularities in the demand for labour, depending upon the arrival of vessels. The unloading of ships was a labour-intensive process, and the employers of waterfront labour engaged workers as required to meet their immediate needs. In order to ensure that there was never a shortage of men at the peak of activity, they retained a

\footnotetext{
${ }^{23}$ Daunton, op. cit., note 15 above, 20.

${ }^{24}$ On the labour market in London, see E. J. Hobsbawm, 'The nineteenth-century London labour market', in R. Glass et al. (eds), London: aspects of change, London, 1964; Stedman Jones, op. cit., note 3 above, part 1; and above all, Charles Booth, Life and labour of the people of London, London, Macmillan, 1902, 17 vols.
} 


\section{Health and housing in Victorian London}

pool of labour by sharing work among its members during periods of lower activity. The result was underemployment of labour, intensified by the fact that the men who formed the core of the dock work-force would be augmented by other workers who could not find employment in their normal trade. This seasonality and irregularity of employment on the waterfront was aggravated by the seasonality in other major sectors such as building, where men were laid off in the winter. These were problems shared by other large ports relying upon the importation of seasonal primary products, such as Liverpool, whose workers therefore faced a comparable housing problem: the need to be close to the waterfront for engagement at short notice and for short periods; an irregular pattern of earnings that made it difficult to rent a house in an area where regular payment of rent was required; and the necessity to be part of a local network of credit, which limited mobility. The uniqueness of London was the addition of two other features.

The demands of London as a centre of conspicuous consumption were also irregular, depending upon the Season. ${ }^{25}$ The arrival in the metropolis of the aristocracy for the spring and early summer, with its round of balls and receptions, created demands for house furnishings and decorations, for servants and coachmen, for milliners and dressmakers, which affected a sizeable part of the London labour market. The goods and services required were highly personalized, and it was not possible to produce them ahead of demand in order to create steady employment. London was in this respect unlike most northern industrial towns where the production of goods in factories was more regular, depending upon the trade cycle in the world economy rather than the immediate short-term demands of clients. This pattern of production was not, however, confined to the luxury trades which were such a feature of the London economy; it also applied to a large extent to the industries that served the bulk of the population of London.

The metropolis had the largest concentration of consumers in the country, and this would make the production of goods in large runs on a regular basis perfectly feasible, unlike in the luxury trades where the pattern of demand made it impossible. Such an outcome was, however, inhibited by other aspects of London's economy. London could not compete with the Midlands and the North, where cheaper land and coal allowed the development of factories which had an incentive to produce on a regular basis in order to earn a return on the capital investment. Many trades such as boot-making and textiles had accordingly left London. Where the metropolis could compete was in trades based upon production at home or in sweat-shops, which minimized expenditure upon power and space, and passed the burdens of adjustment to fluctuations in demand on to a work-force that could be engaged and dismissed at will. ${ }^{26}$ As in the case of the docks, this tied workers to the inner city where such work was available; indeed, these various forms of casual work were often related, for casual employment for the husband often meant outwork for the wife.

This labour market, which relied upon an interrelationship of sectors with different seasonal patterns, was threatened in the $1880 \mathrm{~s}^{27}$ The extension of provincial factory

${ }^{25}$ L. Davidoff, The best circles: Society, etiquette and the Season, London, Croom Helm, 1973.

${ }^{26}$ D. Bythell, The sweated trades: outwork in nineteenth-century Britain, London, Batsford, 1978.

${ }^{27}$ Stedman Jones, op. cit., note 3 above, 153. 


\section{J. Daunton}

production in areas such as ready-made clothing meant competition for London trades; the movement of dock-work further downstream undermined older communities; and the expansion of the City's office district curtailed the inner industrial areas. The result was an intensification of the poverty of the population of the inner city which was not able to move to new areas, and an attempt by employers to compete with their provincial rivals by an intensification of sweating. To this strain in the labour market of inner London was added tension in the housing market.

The housing stock of the inner districts was shrinking, for two reasons. Partly it was a result of commercial development, with the construction of railways, docks, warehouses, and offices. But it was also the outcome of the conscious policies of the previous twenty or thirty years for sanitary and social reform. New streets were driven through the slum districts, to displace the poor and so reduce the charge on the rates; to open the "rookeries" to inspection and control; and to produce "a freer circulation of air [which] would tend materially to extirpate those prevalent diseases which not only ravaged the poorer districts in question, but were also dangerous to the adjacent localities".28

This approach had serious limitations, for it was essentially a sanitary policy applied to individual houses or pockets of property, rather than a housing policy concerned with the processes that created poor conditions. The housing problem was defined in terms of slums which were seen as distinct from the rest of the urban fabric, produced by the faults of the past rather than the failings of the current urban economy. The policy was to excise these "plague spots", which could be defined by the Medical Officers of Health by the death rate and the incidence of disease. The owners of the slums should be compensated in full, since it was believed that they were innocent legatees of the mistakes of the past and not the authors of the poor conditions; and new housing could be left to the free market, aided by philanthropy, under the guidance of regulations designed to prevent the recurrence of insanitary conditions. The problem was not seen as residing in the distribution of income, the structure of the labour market, or the nature of urban industry. The Sanitary Act of 1866 made overcrowding an offence; the Artizans and Labourers Dwellings Act of 1868 allowed local authorities to condemn and demolish insanitary houses; and the Artizans and Labourers Dwellings Improvement Act of 1875 extended these powers to districts. Although some powers of rebuilding were contained in the legislation, they were limited; furthermore, if they were used, the people rehoused were often not those who had been displaced, for they could not afford the rents charged in the new property. The implementation of these measures rested upon the Medical Officers of Health of the metropolis, whose appointment by each local authority in London had been required by the Metropolis Local Mangement Act of $1855 .{ }^{29}$ The approach was not without its problems.

The Medical Officers faced two difficulties. One arose from the fact that their tenure of office was at the pleasure of the Vestry, which might limit their ability to act

\footnotetext{
${ }^{28}$ Ibid., ch. 8; H. J. Dyos, 'Some social costs of railway building in London', J. Transport Hist., 1957-8, 3: 23-30; Owen, op. cit., note 10 above, ch. 5. The quotation is from Stedman Jones, op. cit., note 3 above, 166-7, citing a Select Committee of 1838.

${ }^{29}$ Wohl, Eternal slum, op. cit., note 3 above, chs 4 and 5; J. A. Yelling, Slums and slum clearance in Victorian London, London, Allen \& Unwin, 1986.
} 


\section{Health and housing in Victorian London}

against the interests of property owners. The second problem arose from a growing realization of the limitations of the legislation. The connection between overcrowding and disease was obvious to the medical officers. Dr Buchanan, medical officer of St Giles, remarked in 1857 ,

If you were asked to name a single condition which shall produce at once an excess of zymotic diseases, an excess of consumption and lung diseases, and a larger infantile mortality, the answer is ready and inevitable. You may produce these diseases with most certainty ... if you will only crowd your population together so that they shall breathe sufficiently impure air.

Overcrowding and disease, remarked the Medical Officer of Health for the Strand, "mutually act and react upon each other". It was not clear, however, that the use of legislation at their disposal would be of any assistance: to attack overcrowding in one place might at best merely displace it, and at worst intensify the problem by reducing the stock of cheap accommodation. Displacement might, for some Vestries and Medical Officers, be desirable: their problem had been solved and the rate burden of a poor population contained. The Medical Officer for St Giles, a reception area for the population displaced from the City, used the legislation to force them to move on, and he remarked to the Select Committee considering the impact of the legislation in 1881 that he "was pleased to have got rid of them". This was no consolation for the districts south of the Thames and Hammersmith, to which he indicated that the displaced population had moved. ${ }^{30}$

Even the use of powers of inspection that did not reduce the housing stock, and might produce cleansing, whitewashing and repairs, was not without its problems. It is possible that such sanitary inspections did contribute to a reduction in disease, but some Medical Officers were aware that they needed to contain their zeal. Dr Tripe, the Medical Officer of Hackney, explained the problem:

There is considerable doubt in my mind as to the extent to which the Regulations should be enforced in providing and keeping sanitary arranagements of the poor in an efficient state, as if frequent inspections are made, and the owners and rent-collectors are put to comparatively a large expense, the ordinary rent, which could with difficulty be paid, is increased, and if the additional rent be not paid, the tenants are ejected, to carry a bad example elsewhere ... on the other hand, if due regard be not paid to the sanitary arrangements ... disease may arise in the streets and spread to the adjoining neighbourhood.

Tripe saw the problem as one of the tenants rather than the property: if landlords were forced to repair property which was then misused, "no reasonable rent will pay the cost"; the answer seemed to be to teach the "destructive poor" to reform their habits. He preferred not to use the powers of the Act of 1866, which would only have resulted, he remarked, in 10,000 people sleeping in the street. ${ }^{31}$ By the $1880 \mathrm{~s}$, most Medical Officers had moved from the narrow parochialism of Dr Buchanan to a

\footnotetext{
${ }^{30}$ These opinions of the medical officers are from Wohl, Eternal slum, op. cit., note 3 above, 109 18; and Stedman Jones, op. cit., note 3 above, 189-90.

${ }^{31}$ Ibid., 192-3; Wohl, Eternal slum, op. cit., note 3 above, 117-18.
} 


\section{J. Daunton}

wider appreciation of the consequences of implementing legislation which had been seen as a victory of sanitary reform against the self-interest or indifference of the Vestries.

The assumption behind the "plague spot" approach to housing policy was that the problem of poor conditions did not arise from the nature of the present urban economy, and that the demolition of the mistakes of the past would permit the free market or the five-per-cent philanthropy of such bodies as the Peabody Trust to provide the necessary accommodation at unsubsidized rents, showing that good sanitation and a fair return to capital could be combined. In fact, the implementation of the policy clashed with reality. Slums could not be so easily defined as separate "plague spots" distinct from the rest of the urban fabric, for the areas designated by the Medical Officers contained high-value commercial property and factories. The generous terms of compensation also led to high costs for cleared land, which prevented private enterprise and five-per-cent philanthropy from providing adequate replacement housing. Rents were too high for the residents who had been displaced, and the strict regulations of the block dwellings that were erected were unpopular with many families. The housing policy which had emerged in the 1860 s and 1870 s started to face increased pressure by the late nineteenth century. ${ }^{32}$

The emphasis upon excising "plague spots" was associated with the assumption that it was the character of the poor which was crucial, rather than the nature of employment and industry, or the relationship between rent and wages. This perception was embedded in the stress of five-per-cent philanthropy that rents in the new block dwellings should be paid regularly and the residents' behaviour monitored. It was also expressed in the strategy of taking over existing dwellings and "training" the poor in sanitation and good housekeeping. This was the approach of Octavia Hill and her lady rent collectors, who visited their tenants to instil habits of punctuality in rent payment and to enforce cleanliness. "The people's homes are bad", wrote Miss Hill, "partly because they are badly built and arranged; they are tenfold worse because the tenants' habits and lives are what they are. Transplant them tomorrow to healthy and commodious homes, and they would pollute and destroy them." The scheme should be made to yield five per cent in order to encourage commercial landlords to imitate her approach, and to avoid the demoralization of the poor ${ }^{33}$ The impact of such schemes on the housing stock was, of course, minimal, both directly and in terms of imitation. The emphasis upon "moralizing" the tenants was part of the approach associated with the Charity Organisation Society, which stressed that social problems had an individual basis: the need was to teach the poor to cope through their own resources with the insecurities of life; those who failed because of their fecklessness should be treated in a draconian and punitive manner. ${ }^{34}$ The moral

\footnotetext{
32 Yelling, op. cit., note 29 above; J. White, Rothschild Buildings: life in an East End tenement block. 1887 1920, London and Boston, Routledge \& Kegan Paul, 1980, 54 60; Wohl, Eternal slum, op. cit., note 3 above, ch. 6; J. Tarn, Five per cent philanthropy: an account of housing in urhan areas between 1840 and 1914. Cambridge University Press, 1973.

${ }^{33}$ Wohl, Eternal slum, op. cit., note 3 above, ch. 7: O. Hill, Homes of the London poor, London, 1875, cited in White, op. cit., note 32 above, 54.

${ }^{34}$ C. L. Mowat, The Charity Organisation Society, 1869 1913; its ideas and works, London, Methuen, 1961
} 


\section{Health and housing in Victorian London}

disease of individuals should be treated as well as the sanitary shortcomings of their accommodation.

The dominant approach by the 1880 s was to consider the house as an artefact that might be more or less sanitary and to view the tenant as a moral problem. If the house were insanitary, it should be demolished; if the tenant had been demoralized or degenerated by urban living, he should be re-educated. The solutions which emerged from the debate of the 1880 s over "outcast London" did not mean, as some historians imply, a shift from these attitudes towards an acceptance of the provision of public housing at subsidized rents as the means of allowing tenants sufficient accommodation to prevent overcrowding. The massive research of Charles Booth that resulted in The life and labour of the people of London was one response to the problems of London in the 1880 s, yet he treated the poorest inhabitants of London in much the same way as the Medical Officer of St Giles: they should be removed from London rather than a single parish, and placed in labour colonies where their character might be reformed. This approach owed much to the attitudes which had been dominant up to the 1880s: it still rested upon personal morality and the excision of "plague spots" rather than the structural causes of poverty and poor housing. The removal of Londoners in Booth's lowest class would, by taking them out of competition for work and houses with the classes above them, allow the conditions of those who remained to improve within a free and unregulated market. Alfred Marshall agreed: he aimed to remove the existing surplus population to a colony outside London, and to prevent further undesirable immigrants by strict control of the bottom end of the housing market through tight sanitary regulations. The removal of the "superfluous labour" would, he argued, "compel rich London to pay, as it can well afford to do, high enough wages to cover the cost of good accommodation", so that "the car of progress may roll on till every one in London is properly housed, and every house has adequate free space around it". The solution was one of "helping the feeble and timid to move and carry their work with them", leaving only such work as it was strictly necessary to locate in London. The result would be a strict state regulation of a residuum of society, in order to preserve a free market for the respectable working class. ${ }^{35}$

The other major theme in the debate of the 1880s was the land question, which was given added impetus with the appearance of Henry George's Progress and poverty in 1880. The Liberals had long blamed the system of short leases for the severity of the housing problem in London, a point which had been analysed at inconclusive length by the Select Committee on Town Holdings and which was also considered by the Royal Commission on the Housing of the Working Classes. The view of the radicals was that in explaining poverty and insanitary housing, "the diabolus ex machina was the great ground landlord". Short leases were seen as an unnatural perversion of the market, brought about by the ability of monopoly landowners to impose their will; they were able, by hoarding land, to force up prices, which consequently led to high

\footnotetext{
${ }^{35}$ For Booth, see E. P. Hennock, 'Poverty and social theory in England: the experience of the 1880s', Social Hist., 1976, 1: 67-91; and J. Brown, 'Charles Booth and the labour colonies, 1889-1905', Econ. Hist. Rev., 2nd ser., 1968, 21: 349-60. For Marshall, see his contribution to the debate on The bitter cry: 'The housing of the London poor. I-Where to house them', Contemporary Rev., 1884, 45: 224-31.
} 


\section{J. Daunton}

rents; and as property neared the date of reversion to the ground landlord, it was allowed to deteriorate, often falling into the hands of "house farmers" who sought high returns without regard for the maintenance of the house during the fag-end of the lease. These attacks upon landowners were always susceptible to criticism, for it was by no means obvious that short leases did produce poor housing, as the examples of Mayfair and Bloomsbury suggested. It could, on the contrary, be argued that the ground landlords had a vested interest in maintaining property in good condition so that it had a high value on reversion. The contribution of George was that he moved the argument to a different level, away from leases in particular to an attack on land in general. He argued that the increased value of land was produced by the activity of society in general and that this formed an "unearned increment". If this were removed, lower land prices would allow cheaper housing and, together with a garden-city type of layout, permit lower-density development. Healthy housing and the demise of overcrowding therefore seemed to depend upon an assault upon the landowners, and this was the view adopted by the Liberal government of 1906-14. It was an attempt that was to end in disillusion and disappointment. ${ }^{36}$

Although the "land question" was asked from the 1880s to the First World War, there were other changes in approach to the social problems of London associated with housing of the casual poor. The draconian solutions favoured by Booth and Marshall gave way to one which saw the casual poor as part of the structure of the labour market in its entirety, rather than a separate moral problem. This arose in part from the practical difficulties of implementing the policy prescription of the $1860 \mathrm{~s}$ and 1870s. The policy of the Liberal government of 1906-14 towards the labour market was to introduce minimum wages and trade boards to regulate the rates in the sweated trades, preventing trades from being "parasitical" by reducing the efficiency of labour and forcing families to rely upon supplemental earnings from other family members. This perception arose in part from an extrapolation of Henry George's notion of rent from land to other forms of income: if landowners could receive "unearned income" at the expense of the rest of society, could it not be the case that the owners of sweatshops were benefiting at the expense of other members of society, who bore the costs of ill health and unemployment of the sweated workers? The answer was to make the labour market more efficient, so that all workers received the full value of their labour. It was hoped to remove casual employment by introducing labour exchanges, which would allow men to find work rather than relying upon those employers where they were known; the employers in turn could be certain of finding men when they were needed and so would not need to retain a pool to meet the maximum demand. Such approaches were themselves limited, for they rested upon a belief that the problem was one of organization, that if the labour market could be made more efficient there would be no unemployment. The main advocate

\footnotetext{
${ }^{36}$ Offer, op. cit., note 1 above, is the best account of the reception of George and the genesis of the land campaign; on the earlier debate on leases, see D. A. Reeder, 'The politics of urban leaseholds in late Victorian Britain', International Rev. soc. Hist., 1962, 6: 413-30. On London, see F. Banfield, The great landlords of London, London, Spencer Blackett, 1881?; and H. Lazarus, Landlordism: an illustration of the rise and spread of slumland as evinced on the great estates of the great ground landlords of London, London, General Publishing Co., 1982: the quotation is from p. 5.
} 
of this view, W. H. Beveridge, refused to accept that there could ever be an excess of labour and he denied J. A. Hobson's argument, that demand could be deficient. This recognition nevertheless constituted a major intellectual shift from about 1900 . These approaches were to some extent seen as the solution to the housing problem: more regular earnings would permit working-men to rent better-quality housing; and subsidized housing was not required as a solution to the problem of overcrowding. If wages could be increased and rents reduced by the use of cheap land, then a free market in housing could continue. The extent to which this approach was viable, in view of the low level of building before the First World War, is, of course, controversial, and the LCC had already before 1914 started to move away from the sanitary approach of slum clearance and rehousing in such schemes as Boundary Street to the provision of additional housing on suburban sites such as at White Hart Lane, Tottenham. Perhaps there was already in train an inevitable progression towards such massive council schemes as Becontree and the provision of subsidized accommodation; but in 1914 there could have been no expectation of such massive intervention as was to come in $1919 .{ }^{37}$

\section{III}

The housing of inner London can appear as a record of inadequate responses to an intractable problem, and historians have considered this in most detail, perhaps because they see in this debate the seeds of the massive public intervention of the interwar period. By contrast, the new housing of an improving standard which was built in the surburbs has received much less attention. Overcrowding in London and the ratio of persons to houses continued to deteriorate until the $1890 \mathrm{~s}$, when there were signs that the situation which had seemed so serious and alarming during the debate on The bitter cry of outcast London had stabilized, with hints of improvement. The person-to-house density, a very crude measure of housing standards, had risen from 7.72 in 1851 , to 7.85 in 1881 and 8.02 in 1896 . However, between the censuses of 1891 and 1911 there was some fall in the level of overcrowding. ${ }^{38}$ The problems in the property market which appeared in Edwardian London might have checked building, but it must be remembered that one factor which created the fall in values and profits was the inability to increase rents because of the large number of houses produced during the housing boom at the turn of the century and the consequent high level of vacancies.

House building was highly cyclical, marked by periods of intensive speculative activity succeeded by long periods of low activity. This produced alternating periods of shortages marked by rising rents and sharing of accommodation, and gluts when the tenants could expect a reduction in rents or use their bargaining position to secure a better house or force a landlord to make improvements in order to keep his property

\footnotetext{
${ }^{37}$ Yelling, op. cit., note 29 above. There is an extensive literature on the changing attitudes towards social policy: see, for example, M. Freeden, The new libralism: an ideology of social reform, Oxford, Clarendon Press, 1978; and P. F. Clarke, Liberals and social democrats, Cambridge University Press, 1979. The work of the LCC is described in LCC, Housing of the working classes in London: notes on the action taken between 1855 and 1912 for the better housing of the working classes in London, with special reference to the action taken by the London County Council between the years 1889 and 1912, London, 1913.

38 Wohl, Eternal slum, op. cit., note 3 above, 300-3.
} 


\section{J. Daunton}

in occupancy. Thus in West Ham, the average weekly rent fell from $7 \cdot 2 s$. in 1888 to a minimum of $6.9 \mathrm{~s}$. in 1891 , rising to a peak of $8.4 \mathrm{~s}$. in 1903 , before falling back to $7 \cdot 2 \mathrm{~s}$. in 1905. E. G. Howarth and M. Wilson, who studied the management of house property in this area, found that agents reduced rents or allowed arrears in order to retain good tenants and to minimize the loss on empty homes. ${ }^{39}$ The experience of the inner city can all too easily lead to a view of working-class housing in London based upon a continuing battle between defaulting and destructive tenants on the one hand and rapacious landlords on the other. Much more characteristic of the social relations of housing in London was its relative tranquillity. The building cycle did give the advantage alternately to tenants and landlords, but these swings were expressed through the ability to adjust rents or to secure repairs, not by major tensions that threatened the stability of urban society.

The condition of housing did not only rely upon the ability of builders to keep pace with the population: it was also necessary to consider the provision of services to the houses and changes in the furnishings. Perhaps the most important in terms of health was the extension of a piped water supply. In London in 1888, the daily domestic water consumption was 26.3 gallons per capita in the area of the East London Company, 28.1 gallons in the district served by the Southwark and Vauxhall Company, and 33 gallons in the case of the Grand Junction Company. Houses were invariably connected to a piped water supply, which permitted the extension of water-closets, and so contributed to the reduction of typhoid fever, diarrhoea, and enteric fever. The other major change in domestic technology was the spread of gas to the majority of working-class houses. The crucial development was the slot-meter, which allowed working-class customers to pay for their gas in advance in small amounts, rather than quarterly in arrears. The South Metropolitan Company started to install slot-meters in London in 1892, and by the end of 1898 had fitted 80,115. The working-class demand for gas increased rapidly, and in the South Metropolitan district reached an average of 16,000 cubic feet a year or an eighth of consumption in the district. The gas companies incurred the costs of supplying pipes, fittings, meters, and stoves: the Gas Light and Coke Company invested over $£ 0.5 \mathrm{~m}$ between 1892 and 1898. The spread of the gas-meter was also associated with an extension in the use of gas for cooking: in the case of the South Metropolitan Company, the percentage of consumers supplied with gas-meters rose from 44.5 in 1898 to 70.0 in 1910 , and the percentage with gas-cookers from 64.0 to 79.4 . Furthermore, the cost of gas for lighting fell as a result of the introduction in the 1890s of the Welsbach incandescent mantle, which required only a quarter of the gas for a given level of illumination. The consumption of paraffin, the main source of light in working-class houses by the $1880 \mathrm{~s}$, started to fall. What gas had not yet started to change was heating, which still relied upon coal. It had, however, allowed working-class houses to become better lit and more pleasant in the summer when the coal range was not needed for cooking. ${ }^{40}$

\footnotetext{
${ }^{39}$ E. G. Howarth and M. Wilson, West Ham: a study in social and industrial problems, being the report of the Outer London Inquiry Committee, London, Dent, 1907, 61-2, 116-17, table III; on the building cycle, S. B. Saul, 'House building in England, 1890-1914', Econ. Hist Rev., 2nd ser., 1962-3, 15: 119-37.

40 The changes in water and gas are discussed in Daunton, op. cit., note 15 above, ch. 10.
} 


\section{Health and housing in Victorian London}

These changes in domestic technology were associated with a marked rise in expectation among the tenants of working-class houses during the last quarter of the nineteenth century which, according to some historians, saw the emergence of a new culture of domesticity. This was in part a positive response to the new opportunities given by the marked increase in real wages, and in part a defensive retreat in the face of the undermining of traditional work-place cultures as a result of increases in productivity in response to the falling profit margins of the late nineteenth century. ${ }^{41}$ In his recollections of South London, Fred Willis remarked upon the creation of a "best" room to provide a fitting stage for the new goods. "There is something almost sacred about this choice apartment", he wrote. "One has a nightmare vision of a prancing bronze horse, a silent and motionless clock, mighty 'ornaments' of a funereal nature and glass lustres, a suite of red plush furniture, what-nots, wooden shelves with tortuous carvings, carpet, rug and a piano which nobody plays." The room and its contents were not designed for everyday use, but had an almost sacred and symbolic function for special occasions. ${ }^{42}$ More important in terms of health was the use of cheap floor- and wall-coverings. Machine-printing of wallpaper was developed by 1851 , and the duty was removed in 1861 . Linoleum was produced in 1876 , and was soon used in working-class households. The ability of working-class families to purchase these coverings possibly contributed to the reduction in tuberculosis, although the new consumer goods were as much "incontrovertible evidence of character and position" as contributions to the health of housing. ${ }^{43}$

There was not only an improvement in domestic technology at the end of the nineteenth century, but also in transport, which freed the regularly-employed from residence in the centre of London. The introduction of cheap fares, particularly in north-eastern London with the implementation of the Cheap Trains Act of 1883, and the provision of horse and later electric trams, gave access to cheaper land in the suburbs. The annual number of journeys per person on railways, trams, and buses rose from 68.5 at the time of the debate on "outcast London" in 1884 , to 128.7 in 1901. This was a major contribution to the health of London. Changes in metropolitan transport, by breaking the stranglehold which had developed in the 1880 s in the housing market of inner London, had a role second only to sanitation in improving housing conditions. ${ }^{44}$

Improvement there certainly was at the end of the century, yet the relationship between rents and wages in London remained more unfavourable than almost anywhere else in England, ${ }^{45}$ and, although most of the new houses were selfcontained and designed for occupation by a single family, sub-letting was extremely

\footnotetext{
${ }^{41}$ G. Stedman Jones, 'Working-class culture and working-class politics in London, 1870-1900: notes on the remaking of a working-class', J. soc. Hist., 1973-4, 7: 460-508.

${ }^{42}$ F. Willis, 101 Jubilee Road: a book of London yesterdays, London, Phoenix House, 1948, 102-3.

${ }^{43}$ Some of these changes are described in W. H. Fraser, The coming of the mass market, 1850-1914, London, Macmillan, 1981. The quotation is from M. E. Loane, An Englishman's castle, London, Edward Arnold, 1909, 55.

${ }^{44}$ Stedman Jones, op. cit., note 3 above, 234; A. S. Wohl, 'The housing of the working classes in London, 1815-1914', in S. D. Chapman (ed.), The history of working-class housing: a symposium, Newton Abbot, David \& Charles, 1971, 29-33.

${ }^{45}$ Rents and wages in London and provincial towns are given in PP 1908 CVII, Report of an enquiry by the Board of Trade into working-class rents, housing and retail prices.
} 


\section{J. Daunton}

common. In $1911,71.0$ per cent of the population of London county were either renting or letting shared accommodation, a figure surpassed only by Plymouth $(83.4$ per cent) and Devonport (90.6 per cent) ${ }^{46}$ Overcrowding, defined as the percentage of the population living at a density of more than two persons per room, was also higher than in provincial towns, with the exception of some in north-east England (table 3).

TABLE 3. PERCENTAGE OF POPULATION IN PRIVATE FAMILIES LIVING OVER TWO PER ROOM, 1911

\begin{tabular}{lrlr}
\hline London county & 17.8 & & \\
Finsbury & 39.8 & Gateshead & 33.7 \\
Shoreditch & 36.6 & Newcastle & 31.6 \\
Islington & 20.0 & Plymouth & 17.5 \\
Camberwell & 13.5 & Leeds & 11.0 \\
Stoke Newington & 8.8 & Liverpool & 10.1 \\
Wandsworth & 6.3 & Blackburn & 4.4 \\
\hline
\end{tabular}

Source: Census of England and Wales, 1911, vol. 8, table 3

The continuance of the serious pressure on housing in the inner city must be explained by the survival into the Edwardian period of the problems of the casual labour market, and a pattern of high prices for land wanted for other uses, which made the construction of working-class housing in these areas difficult. Despite the improvement that had taken place in London's housing, there were still serious problems in certain areas. Yet the more appropriate comparison is not with the provincial towns of England: it is with the other great metropolises and capitals of the industrial world. On this criterion, the point which stands out is the high standard of accommodation in London in comparison with Berlin, or Paris, or Vienna, or New York where the real cost of housing was higher and the level of overcrowding greater. Whether the relative level of housing costs and standards affected the patterns of mortality in these cities, or whether there were other factors which could compensate for the influence of accommodation, is a question that raises many issues for urban and demographic historians to consider in the future. ${ }^{47}$

${ }^{46}$ Census of England and Wales, 1911, vol 6, table 2.

${ }^{47}$ See the collection of essays which considers housing conditions but which does not analyse the demographic consequences: M. J. Daunton (ed.), Housing the workers, 1850-1914: a comparative history, Leicester University Press, 1990; see also D. J. Olsen, The city as a work of art: London, Paris, Vienna, New Haven, Conn., and London, Yale University Press, 1986. 